\title{
Fast and Effective Thermotherapy Treatment for In Vitro Virus Eradication in Apple and Pear Trees
}

\author{
Analí Lizárraga' ${ }^{1}$, Javier Ascasíbar², María Luz González ${ }^{1}$ \\ ${ }^{1}$ Department of Plant Physiology, University of Santiago de Compostela, Santiago de Compostela, Spain \\ ${ }^{2}$ Center of Agrarian Research of Mabegondo INGACAL-CIAM, Abegondo, Spain \\ Email:mluzgonzalez@usc.es
}

How to cite this paper: Lizárraga, A., Ascasíbar, J. and González, M.L. (2017) Fast and Effective Thermotherapy Treatment for In Vitro Virus Eradication in Apple and Pear Trees. American Journal of Plant Sciences, 8, 2474-2482.

https://doi.org/10.4236/ajps.2017.810168

Received: July 24, 2017

Accepted: September 17, 2017

Published: September 20, 2017

Copyright (c) 2017 by authors and Scientific Research Publishing Inc. This work is licensed under the Creative Commons Attribution International License (CC BY 4.0).

http://creativecommons.org/licenses/by/4.0/

\begin{abstract}
Heat therapy followed by the isolation and in vitro culture of apical meristems is a suitable procedure for virus eradication. However, the period of heat treatment is usually long (28 - 50 days) and the yield of viable plants free of viruses after treatment is often low $(<50 \%)$. Here, we describe an alternative method to obtain virus-free plants. We used traditional Galician cultivars, six apple trees and two pear trees, infected with Apple chlorotic leaf spot virus (ACLSV) and Apple mosaic virus (ApMV). We combined heat therapy of in vitro shoots using a temperature gradient from $25^{\circ} \mathrm{C}$ to $40^{\circ} \mathrm{C}$ increasing $1^{\circ} \mathrm{C}$ per day for a shorter period of time (18 days) with the posterior isolation and culture of apical meristems. All DNA samples analyzed, obtained from plants developed from meristems, were 100\% free of ApMV and almost 90\% free of ACLSV. With this in vitro procedure combined we obtained a good yield of tested plants free of viruses. Our method is fast and effective and it could be also useful to eradicate these and other viruses in other fruit trees.
\end{abstract}

\section{Keywords}

Heat Therapy, Meristem Culture, ACLSV, ApMV, Malus, Pyrus

\section{Introduction}

Having healthy plant material is an important action to avoid loss of productivity, due to virus infection of fruit trees. Apple chlorotic leaf spots virus (ACLSV) and Apple mosaic virus (ApMV) are main responsible for viral diseases in Pyrus and Malus trees [1] [2], provoking growth retardation and loss of productivity. ACLSV infection is also widespread in stone fruit trees species, causing disease 
to plums [3]. These viruses can be transmitted mechanically and disseminated by infected propagation material [4]. The viruses are transmissible by grafting and persist in the vegetative propagation material of infected trees being probably the main source of inoculums. There are neither known vectors nor other ways of natural transmission for these viruses [5] [6]. Therefore, cultivation of virus-free plants has the advantage of preventing other plants or fruit trees from being contaminated by these viruses.

Viruses are dispersed in the plant by the xylem and phloem and for this reason it is assumed that the meristems, lacking vascular connection, are free of virus. Isolation and in vitro cultivation of meristems is a widely used method for virus eradication from horticultural plants [7]. However, the efficiency of such method is usually very low because it is difficult to isolate and regenerate shoots from very small apical meristems $(<0.20 \mathrm{~mm})$ [8]. On the other hand, in vivo/ in vitro thermotherapy can reduce virus titers in plants and improve efficacy for eradication [9]. Although the success of virus eradication by thermotherapy will depend largely on the type of virus and plant species [10], the duration of treatment at high temperatures is directly associated with a decrease in the presence of viruses in the plant. Application of alternate night/day temperatures for a high number of days yielded low percentages of virus-free pear tree plants while higher temperatures improved the percentage of virus-free plants (up to $100 \%$ ) but only if they are extended for a longer period [11].

Several procedures have being developed combining thermotherapy that slows the multiplication of viruses, with the technique of isolation of apical meristems in vitro. This combination has been shown to be effective [12] [13] although the percentage of recovery of viable plants free of virus was relatively low. Thermotherapy is most frequently performed at $36^{\circ} \mathrm{C}-38^{\circ} \mathrm{C}$ for $21-35$ days [14]. However, maintaining high temperatures for long periods of time has a negative effect on the survival and growth of meristems even though it is more effective in achieving high rates of virus-free plants [15]. New methods, like organogenesis, have tried to get higher rates from adventitious buds but they failed to eradicate viruses [16].

\section{Materials and Methods}

Before starting our procedure for virus eradication, virus status in traditional cultivars of Galicia in apple and pear field plants belonging to the CIAM Germplasm Bank (Mabegondo Agricultural Research Center, NW Spain) was determined by Double Antibody Sandwich Enzyme Linked Inmunosorbent Assay (DAS-ELISA, Bioreba, Nyon Switzerland). According to these analyses all selected cultivars tested positive for ACLSV and the ApMV viruses. After confirming the viral infection, in vitro cultures were started from terminal shoots of annual cuttings collected in January 2012, 2013 and 2014. These cuttings were from six apple (Malus $\times$ domestica) cultivars "Cacharela”, "Camoesa”, "Gravillán”, “Ollo Mouro", "José Antonio" and "Príncipe Grande", and two pear cultivars (Pyrus communis) "Barburiña" and "Manteca Oscura". All of them, belonging to a twelve-year-old 
tree plantation, were characterized genetically [17]. Until now, these six traditional apple and two pears cultivars of NW of Spain had never been micropropagated. For their conservation and recovery, virus eradication is obligated according to the European and Mediterranean Plant Protection Organization (EPPO) [18], and would also allow to recover old cultivars and to maintain a sustainable agriculture.

Three alternative methods of thermotherapy were tested in order to achieve one that was to be effective for eradicating viruses and, at the same time, would not affect the survival of shoots. The first method was applied by immersing the cut stakes, approximately $20 \mathrm{~cm}$ in length, in distilled water into sealed plastic bags in a thermostatic bath at a constant temperature of $51^{\circ} \mathrm{C}$ or $56^{\circ} \mathrm{C}$ for one hour. The second method was carried out with cuttings of about $12-15 \mathrm{~cm}$ in length, lying in test tubes with distilled water in an incubator, gradually increasing the temperature, $1^{\circ} \mathrm{C}$ per day, from $25^{\circ} \mathrm{C}$ up to $40^{\circ} \mathrm{C}$, until sprout development. A third method, also with gradual increase of temperature (from $25^{\circ} \mathrm{C}$ to $40^{\circ} \mathrm{C}$ ), developed in our laboratory, was applied to shoots grown in vitro, in jars, in a solid mineral medium with presence of a cytokinin and auxin. This last method was the one used in the present study.

To establish plant material for in vitro culture, apical tips $(1.0-1.5 \mathrm{~mm})$, from developed axillary buds were excised sterilized with $10 \%$ sodium hypochlorite solution plus one drop of Tween $20^{\circledR}$ for 15 minutes, washed three times with sterile distilled water in order to remove traces of chlorine and placed on a mineral medium MS with modified vitamins (thiamine 10x) [19] supplemented with sucrose $3 \%(\mathrm{w} / \mathrm{v}), 1.0 \mathrm{mg} \cdot \mathrm{L}^{-1}$ 6-benzyladenine (BA), $0.3 \mathrm{mg} \cdot \mathrm{L}^{-1}$ indol 3-butiric acid (IBA) and $0.2 \mathrm{mg} \cdot \mathrm{L}^{-1}$ gibberellic acid $\left(\mathrm{GA}_{3}\right)$, and solidified with $0.7 \%(\mathrm{w} / \mathrm{v})$ Micro agar (Duchefa). The $\mathrm{pH}$ was adjusted to 5.8 before autoclaving at $121^{\circ} \mathrm{C}$ for 20 minutes. After four weeks cultured in this medium the explants were transferred to tubes $(50 \mathrm{~mL})$ with the same medium but without $\mathrm{GA}_{3}$ twice. Then they were transferred to jars and they remained subcultured every four weeks until they multiplied. All cultures were transferred to a growth chamber with a 16 hours photoperiod under the following conditions: $24^{\circ} \mathrm{C} \pm 1^{\circ} \mathrm{C}$ day, with a light irradiancy of $40 \mu \mathrm{mol} \cdot \mathrm{m}^{-2} \cdot \mathrm{s}^{-1}$ illuminated by white fluorescent lamps $\left(50 \mathrm{~W} \mathrm{Osram}^{\circ}\right.$ ), and $18^{\circ} \mathrm{C} \pm 1^{\circ} \mathrm{C}$ night. Every four weeks the obtained shoots were subcultured on a fresh medium with the same composition in which only the concentration of added BA varied depending on the cultivar. We used MS mineral medium with BA $0.25 \mathrm{mg} \cdot \mathrm{L}^{-1}$ and IBA $0.1 \mathrm{mg} \cdot \mathrm{L}^{-1}$ for "Cacharela", "Camoesa", "Gravillán" and "Ollo Mouro"; MS BA $0.5 \mathrm{mg} \cdot \mathrm{L}^{-1}$ and IBA $0.1 \mathrm{mg} \cdot \mathrm{L}^{-1}$ for "José Antonio" and "Príncipe Grande", all of them apple cultivars, and mineral medium MS with BA $1 \mathrm{mg} \cdot \mathrm{L}^{-1}$ for pears cultivars "Barburiña" and "Manteca Oscura" [20].

\section{In Vitro Thermotherapy Treatment}

After seven months since established in vitro and multiplied, the plant material was ready for thermotherapy. Two weeks after the last subculture, the heat ther- 
apy was applied to 30 in vitro shoots per each cultivar using an incubator with continuous source of cool white light at half irradiancy $\left(17 \mu \mathrm{mol} \cdot \mathrm{m}^{-2} \cdot \mathrm{s}^{-1}\right)$ in comparison with growth chamber light conditions; temperature was gradually increased $\left(1^{\circ} \mathrm{C} /\right.$ day) from $25^{\circ} \mathrm{C}$, the first day, up to $40^{\circ} \mathrm{C}$, remaining three days at this last temperature. The total duration of the process was 18 days, a shorter period than the previous described methods [11] [14].

After heat therapy for meristem isolation and clonal multiplication, shoot tips $(0.7-1.0 \mathrm{~mm})$ larger than the apical meristems $(<0.20 \mathrm{~mm})$ were excised. This size facilitated their isolation and cultivation, improving the survival rate. For each cultivar, shoot tips were cultured in Petri dishes with $25 \mathrm{~mL}$ of culture medium selected, above described, which we covered with sterile filter paper disks and they were placed 4 weeks in a growth chamber at $24^{\circ} \mathrm{C}$ under established light conditions.

Each viable and non hyperhydric survivor meristem of each cultivar was enumerated and multiplied to constitute a clone. The shoots developed were subcultured every four weeks in the same specific medium for each cultivar, during seven months. After this period and to check the presence of viruses, the resulting material was analyzed by DAS-ELISA, according to the manufacturer's instructions. For conventional RT-PCR analysis, first, RNA was obtained from 400 $\mu \mathrm{L}$ extract of the crushed tissue from shoots derived from each of the apical meristems cultured in vitro using peqGOLD Plant RNA kit (PEQLAB Biotechnologies $\mathrm{GmbH}$, Deutschland). RT-PCR was carried out according to the manufacturer's instructions (Takara Bio Inc., Japan), using the specific primers for ApMV $1 \mathrm{~F}$ and $8 \mathrm{~F}$ for ACLSV adapted for detection of apple virus [12]. The conventional RT-PCR was performed on a thermocycler (Applied Biosystems 7300) using a program consisting of 1 cycle at $42^{\circ} \mathrm{C}$ for 5 minutes, 1 cycle at $95^{\circ} \mathrm{C}$ for 10 seconds, 40 cycles of $95^{\circ} \mathrm{C}$ for 5 seconds and $55^{\circ} \mathrm{C}$ for 30 seconds. The complete procedure for virus eradication is represented in the schematic diagram in Figure 1.

\section{Results and Discussion}

Only the third thermotherapy method used, applied to shoots grown in vitro with gradual increase of temperature from $25^{\circ} \mathrm{C}$ to $40^{\circ} \mathrm{C}$ during 18 days, was effective. Efficacy for virus eradication was evaluated based on the rate of regeneration of tested plants free of viruses in six apple and two pear cultivars and on survival rates. The results obtained with a sample size of 30 are summarized in Table 1. The good results were probably due to the combination of four factors: the use of a temperature gradient, the shortening of heat treatment, the application of thermotherapy to shoots previously subcultured in fresh media for two weeks and the bigger size of isolated apical meristems.

It is worth noting that the effectiveness of the in vitro thermotherapy depends largely on the type of virus and plant genotype. According to a previous work in pear tree [10], in our research we obtained $100 \%$ virus-free tested plants only for 


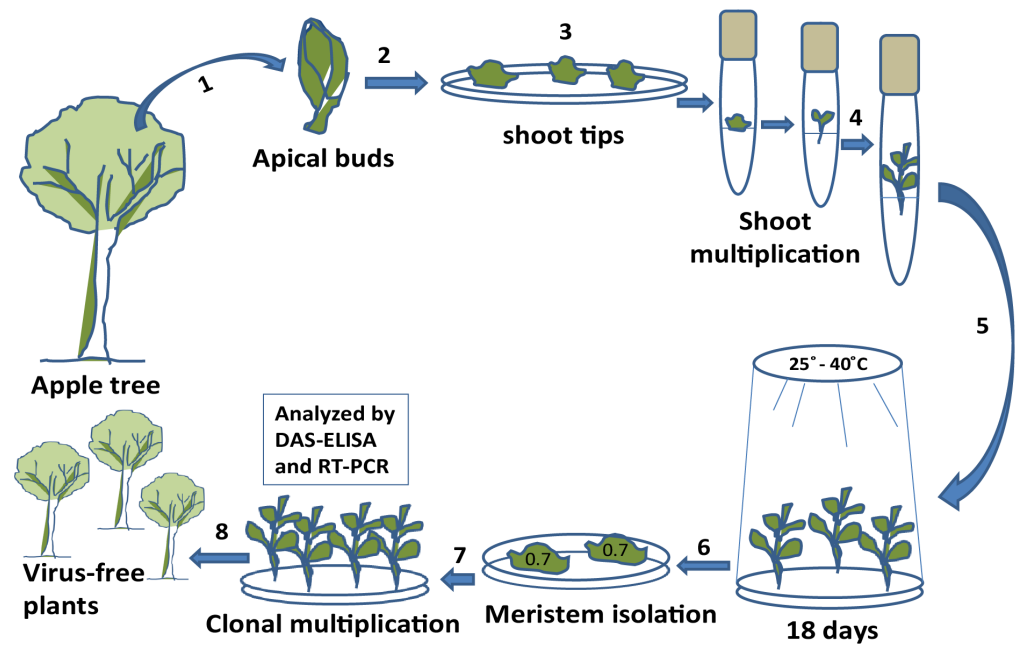

Figure 1. Schematic diagram of the complete thermotherapy process and culture of apical meristems: 1) Infected plant in the field; 2) Establishment in vitro cultures; 3) Isolation of apical shoots and culture; 4) Shoots multiplication; 5) Application of gradual heat therapy; 6) Isolation and culture of apical meristems; 7) New shoots development and DAS-ELISA and RT-PCR analysis; 8) Plants free of viruses.

Table 1. Percentage of virus free plants of apple and pear tree cultivars treated with thermotherapy using DAS-ELISA and RT-PCR analyses.

\begin{tabular}{lcccc}
\hline Cultivars & $\begin{array}{c}\text { Thermotherapy } \\
\text { survival (\%) }\end{array}$ & $\begin{array}{c}\text { Viable clones } \\
\text { analyzed }\end{array}$ & \multicolumn{2}{c}{ Virus free plants (\%) } \\
ApMV & ACLSV \\
\hline "Cacharela" & 63 & 07 & 100 & 57 \\
"Camoesa" & 50 & 03 & 100 & 100 \\
"Gravillán" & 100 & 27 & 100 & 96 \\
"José Antonio" & 46 & 10 & 100 & 100 \\
"Ollo Mouro" & 86 & 06 & 100 & 100 \\
"Príncipe Grande" & 46 & 07 & 100 & 100 \\
"Barburiña"* & 46 & 06 & 100 & 100 \\
"Manteca Oscura"* & 56 & 13 & 100 & 100 \\
\hline
\end{tabular}

${ }^{\star}$ Pear cultivars; ${ }^{* *}$ All survivor clones after 7 months of multiplication.

ApMV, independently of the cultivar (Figures 2(a)-(d)). However, for ACLSV only $96 \%$ and $57 \%$ virus-free results were obtained in the cultivars of "Gravillán" and "Cacharela", respectively. We could not achieve 100\% virus free plants on those two cultivars because did not well tolerate the high temperatures and some terminal shoot tips was damaged. In the remaining cultivars, including pear trees, $100 \%$ of ACLSV virus-free tested plants were obtained.

Although the high temperatures applied over prolonged periods of time are more effective for virus eradication they also reduce the viability of the shoots cultured in vitro as well as their survival [15]. In our case the duration of heat 


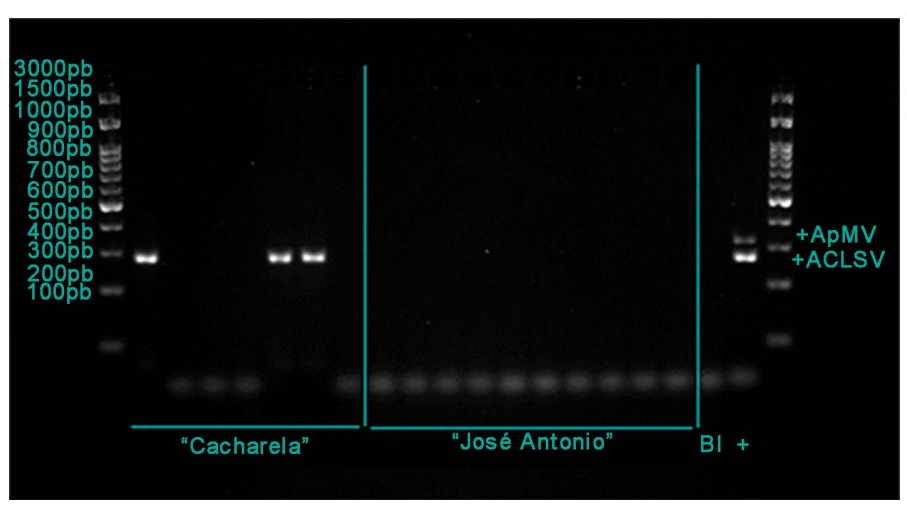

(a)

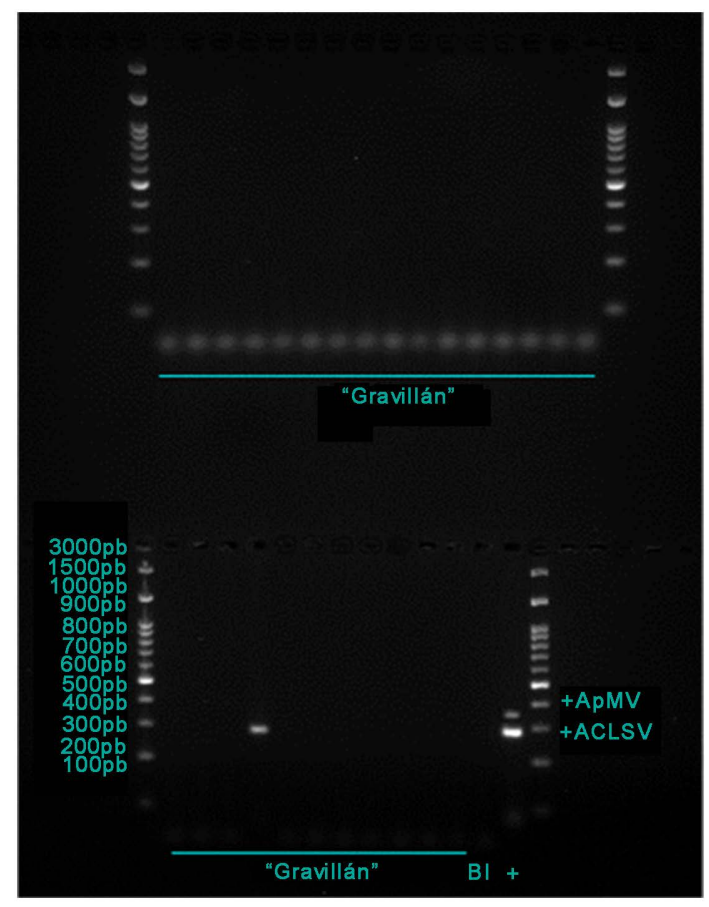

(c)

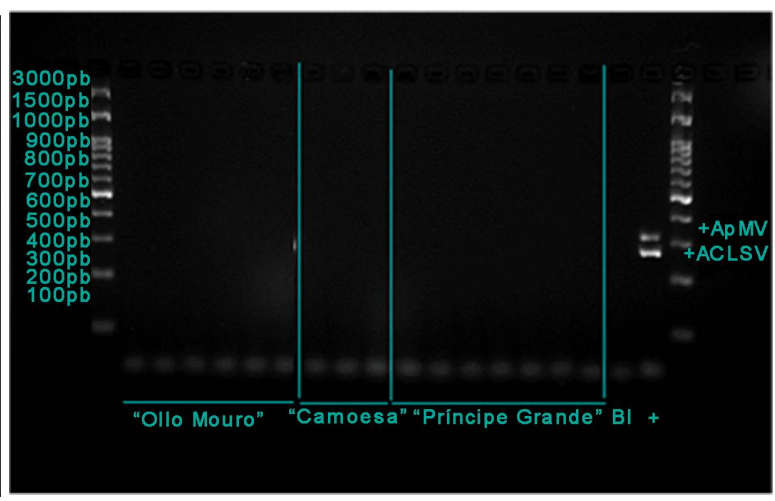

(b)

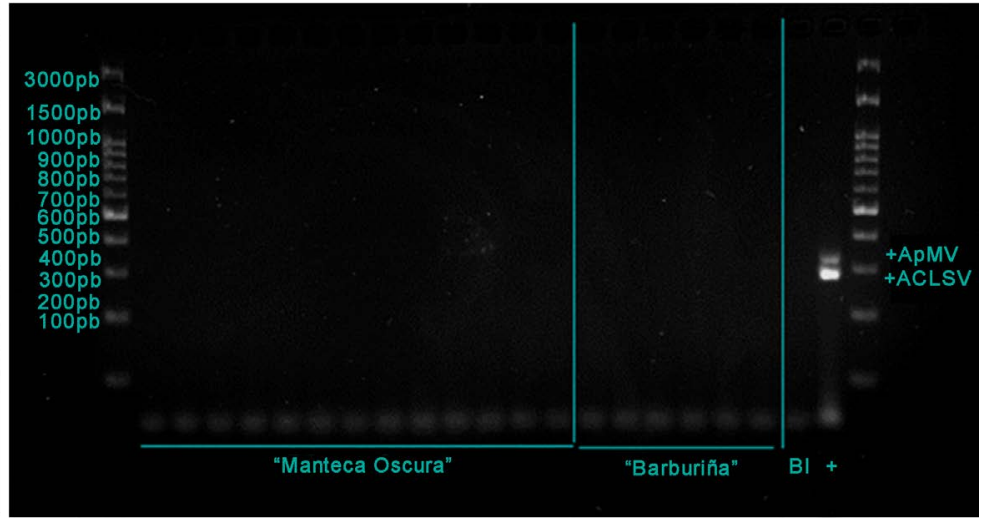

(d)

Figure 2. Results of the electrophoresis of the RT-PCR product from all the analyzed samples, for both viruses, for apple tree cultivars 2. (a) "Cacharela" and "José Antonio"; (b) “Ollo Mouro", "Camoesa” and "Príncipe Grande”; (c) "Gravillán”; and (d) for pear tree cultivars "Manteca Oscura" and "Barburiña”.

therapy was only of 18 days but, despite this, it was very effective both in the survival and the eradication of the two types of virus, probably due to the gradual increase of $1^{\circ} \mathrm{C}$ per day, which allowed plants to adapt to high temperatures without suffering damages for their survival, and also to enduring $40^{\circ} \mathrm{C}$ during three days.

Some authors stated that alternating temperatures of $38^{\circ} \mathrm{C} / 32^{\circ} \mathrm{C}$ day/night applied to shoots for 50 days produced low percentages of virus-free pear plants, while at higher temperatures of $42^{\circ} \mathrm{C}$ and $34^{\circ} \mathrm{C}, 100 \%$ of virus-free plants were obtained but only if applied for 60 days [11], a period too long for survival.

On the other hand, the size of the isolated meristems after thermotherapy also plays a decisive role in survival and recovery once it is cultured again. Sizes of 
apple meristems of $0.3 \mathrm{~mm}$ showed a survival of $40 \%-50 \%$, whereas for those of $1 \mathrm{~mm}$ the recovery rate was $80 \%-95 \%$ [22]. It is possible to obtain virus-free plants from apical meristems of small size but these have less survival capacity [8]. Furthermore, the isolation and cultivation of $0.5 \mathrm{~mm}$ apple meristems with 3 - 4 leaf primordia was not effective for virus eradication while isolation of meristems with only the initiation of two leaf primordia produced $100 \%$ of virus-free plants [23]. In our case, the isolation of larger meristematic apices, between 0.7 and $1.0 \mathrm{~mm}$, was very effective in the eradication of virus while improving the percentages of survival of tested virus-free plants of both apple and pear cultivars.

We have verified that the combination of heat therapy to buds at the right moment of growth ( 2 weeks after subculture), together with isolation of larger terminal apices $(0.5-0.7 \mathrm{~mm})$ and a gradual increase in temperature from $25^{\circ} \mathrm{C}$ to $40^{\circ} \mathrm{C}$ for a short period of time (18 days), greatly increases the effectiveness of the method.

The purpose of our study was to develop an efficient procedure with shorter time of heat treatment using high temperatures but without affecting the survival of the treated shoots, isolating small apical shoots between $0.7-1.0 \mathrm{~mm}$, with the meristem tip, which were more apt to survive and achieve a high percentage of success in eradicating viruses in apple and pear trees.

\section{Conclusion}

We can conclude that our work brings some innovations to the heat therapy method, with clear advantages in eradicating viruses and favoring the survival of the explants. This protocol of thermotherapy in vitro with gradual increase of temperature shortens the therapy time to only 18 days. Heat therapy was applied to in vitro cultured explants inside the jars, and the novelty is that they are always subcultivated 14 days before being treated with heat. This fact makes that the shoots are in a period of active growth and they support better the gradual increase of $1^{\circ} \mathrm{C}$ per day until reaching the temperature of $40^{\circ} \mathrm{C}$, enhancing the survival rate of isolated explants. Moreover, the isolated apexes of meristems had a size between $0.7-1.0 \mathrm{~mm}$, which greatly improves their survival in culture contrary to isolating them of a smaller size (data not shown). The fact of combining short-time thermotherapy with the utilization of greater initial size of the isolated explants, allows a higher yield of both survival and virus-free plants, achieving $100 \%$ of ApMV and ACLSV virus eradication in the six apples and two pear cultivars. This protocol could be applicable to other species of fruit trees or to other apple and pear trees cultivars for virus eradication.

\section{Acknowledgements}

The authors sincerely thank Dr. Jaime Gómez Márquez for his critical review of the manuscript and their useful suggestions. To Mrs. Olga Rivero de Aguilar for make a revision and correction of English of manuscript. We also acknowledge to the CIAM germplasm bank of the Mabegondo Agricultural Research Center 
(INGACAL) for the agreement signed for the transfer of plant material from Malus and Pyrus to our laboratory at the University of Santiago de Compostela.

\section{References}

[1] Lister, R.M. (1970) Apple Chlorotic Leaf Spot Virus C.M.I/A.A.B. Description of Plant Viruses No.30. Purdue University, Lafayette.

[2] Mink, G.I. (1992) Ilarvirus Vectors. In: Harris, K.F., Ed., Advances in Disease Vector Research, Springer, New York, 261-281.

https://doi.org/10.1007/978-1-4612-2910-0_8

[3] Gella, R. and Errea, P. (1998) Application of In vitro Therapy for Ilarvirus Elimination in Three Prunus Species. Journal of Phytopathology, 146,445-449. https://doi.org/10.1111/j.1439-0434.1998.tb04779.x

[4] Fulton, R.W. (1972) Apple Mosaic Virus CMI/AAB Descriptions of Plant Viruses, No. 83. Association of Applied Biologists, Wellesbourne.

[5] Wang, L.P., Hong, N., Wang, G.P., Xu, W.X., Michelutti, R. and Wang, A.M. (2010) Distribution of Apple Stem Grooving Virus and Apple Chlorotic Leaf Spot Virus in Infected In Vitro Pear Shoots. Crop Protection, 29, 1447-1451.

https://doi.org/10.1016/j.cropro.2010.08.003

[6] Ji, Z., Zhao, X., Duan, H., Hu, T., Wang, S., Wang, Y. and Cao, K. (2013) Multiplex RT-PCR Detection and Distribution of Four Apple Viruses in China. Acta Virologica, 57, 435-441. https://doi.org/10.4149/av_2013_04_435

[7] Panattoni, A., Luvisi, A. and Triolo, E. (2013) Review. Elimination of Viruses in Plants: Twenty Years of Progress. Spanish Journal of Agricultural Research, 11, 173-188. https://doi.org/10.5424/sjar/2013111-3201

[8] Paprstein, F., Sedlak, J., Polak, J., Svobodova, L., Hassan, M. and Bryxiova, M. (2008) Results of In Vitro Thermotherapy of Apple Cultivars. Plant Cell, Tissue and Organ Culture, 94, 347-352. https://doi.org/10.1007/s11240-008-9342-8

[9] Mink, G.I., Wample, R. and Howell, W.E. (1998) Heat Treatment of Perennial Plants to Eliminate Phytoplasmas, Viruses, and Viroids While Maintaining Plant Survival. In: Hadidi, A., Ed., Plant Virus Disease Control, Springer, St. Paul.

[10] Cieślińska, M. (2002) Elimination of Apple Chlorotic Leaf Spot Virus (ACLSV) from Pear by In Vitro Thermotherapy and Chemotherapy. ISHS Acta Horticulturae 596: VIII International Symposium on Pear, 481-484. https://doi.org/10.17660/ActaHortic.2002.596.80

[11] Tan, R., Wang, L., Hong, N. and Wang, G. (2010) Enhanced Efficiency of Virus Eradication Following Thermotherapy of Shoot-Tip Cultures of Pear. Plant Cell, Tissue and Organ Culture, 101, 229-235. https://doi.org/10.1007/s11240-010-9681-0

[12] Manganaris, G.A., Economou, A.S., Boubourakas, I.N. and Katis, N.I. (2003) Elimination of PPV and PNRSV through Thermotherapy and Meristem-Tip Culture in Nectarine. Plant Cell Reports, 22,195-200. https://doi.org/10.1007/s00299-003-0681-y

[13] Zilka, S., Faingersh, E., Rotbaum, A., Tam, Y., Spiegel, S. and Malca, N. (2002) In Vitro Production of Virus-Free Pear Plants. Acta Horticulturae, 596, 477-479. https://doi.org/10.17660/ActaHortic.2002.596.79

[14] Knapp, E., Hanzer, V., Weiss H, H., da Câmara Machado, A., Weiss, B., Wang, Q., Katinger, H. and Laimer da Câmara Machado, M. (1995) New Aspects of Virus Elimination in Fruit Trees. Acta Horticulturae, 386, 409-418.

https://doi.org/10.17660/ActaHortic.1995.386.56 
[15] Wang, L.P., Wang, G.P., Hong, N., Tang, R.R. and Deng, X.Y. (2006) Effect of Thermotherapy on Elimination of Apple Stem Grooving Virus and Apple Chlorotic Leaf Spot Virus for In Vitro Cultured Pear Shoot Tips. HortScience, 41, 729-732.

[16] Wang, M.R., Li, B.Q., Feng, C.H. and Wang, Q.C. (2016) Culture of Shoot Tips from Adventitious Shoots Can Eradicate Apple Stem Pitting Virus But Fails in Apple Stem Grooving Virus. Plant Cell, Tissue and Organ Culture, 125, 283-291. https://doi.org/10.1007/s11240-016-0948-y

[17] Pereira-Lorenzo, S., Ramos-Cabrer, A.M. and Díaz-Hernández, M.B. (2007) Evaluation of Genetic Identity and Variation of Local Apple Cultivars (Malus x domesticaBorkh.) from Spain Using Microsatellite Markers. Genetic Resources and Crop Evolution, 54, 405-420. https://doi.org/10.1007/s10722-006-0003-7

[18] EPPO (1999) EPPO Standars PM 4/27(1) Certification Schemes Malus, Pyrus and Cydonia. European Plant Organization, Paris.

[19] Murashige, T. and Skoog, F. (1962) A Revised Medium for Rapid Growth and Bio Assays with Tobacco Tissue Cultures. Physiologia Plantarum, 15, 473-497. https://doi.org/10.1111/j.1399-3054.1962.tb08052.x

[20] Lizárraga, A., Fraga, M., Ascasíbar, J. and González, M.L. (2017) In Vitro Propagation and Recovery of Eight Apple and Two Pear Cultivars Held in a Germplasm Bank. American Journal of Plant Science, 8, 2238-2254. https://doi.org/10.4236/ajps.2017.89150

[21] Massart, S., Brostaux, Y., Barbarossa, L., Batlle, A., Cesar, V., Dutrecq, O., Fonseca, F., Guillem, R., Komorowska, B., Olmos, A., Steyer, S., Wetzel, T., Kummert, J. and Jijakli, M.H. (2009) Interlaboratory Evaluation of Two Reverse-Transcriptase Polymeric Chain Reaction-Based Methods for Detection of Four Fruit Tree Viruses. Annals of Applied Biology, 154, 133-141. https://doi.org/10.1111/j.1744-7348.2008.00281.x

[22] Plopa, C. and Preda S. (2013) Elimination of Apple Mosaic Virus by Tissue Culture of Some Infected Apple Cultivars. International Society for Horticultural Science, 981, 517-522. https://doi.org/10.17660/ActaHortic.2013.981.83

[23] Li, B.Q., Feng, F.C., Hu, L.Y., Wang, M.R. and Wang, Q.C. (2016) Shoot Tip Culture and Cryopreservation for Eradication of Apple Stem Pitting Virus (ASPV) and Apple Stem Grooving Virus (ASGV) from Apple Rootstocks 'M9' and 'M26'. Annals of Applied Biology, 168, 142-150. https://doi.org/10.1111/aab.12250

Submit or recommend next manuscript to SCIRP and we will provide best service for you:

Accepting pre-submission inquiries through Email, Facebook, LinkedIn, Twitter, etc. A wide selection of journals (inclusive of 9 subjects, more than 200 journals)

Providing 24-hour high-quality service

User-friendly online submission system

Fair and swift peer-review system

Efficient typesetting and proofreading procedure

Display of the result of downloads and visits, as well as the number of cited articles

Maximum dissemination of your research work

Submit your manuscript at: http://papersubmission.scirp.org/

Or contact ajps@scirp.org 